\title{
First case of ivermectin-induced severe hepatitis
}

\section{Olivia Veit ${ }^{a, *}$, Bernhard Beck $^{a}$, Michael Steuerwald $^{b}$, Christoph Hatz $^{\mathrm{a}}$}

\author{
a Swiss Tropical Institute, Medical Department, Socinstrasse 57, 4002 Basle, Switzerland \\ b University Hospital, Department of Gastroenterology \& Hepatology, 4002 Basle, Switzerland
}

Received 9 May 2005; received in revised form 26 February 2006; accepted 27 February 2006

Available online 8 May 2006

\section{KEYWORDS \\ Loiasis; \\ Loa loa; \\ Ivermectin; \\ Liver disease; \\ Drug-induced \\ hepatitis}

\begin{abstract}
Summary Loiasis, caused by the filarial parasite Loa loa, is endemic in West and Central Africa. Ivermectin has been shown to be an effective treatment of loiasis. We report the case of a 20-year-old woman originally from Cameroon who was infected by the L. loa parasite and developed severe hepatitis, identified 1 month after a single dose of ivermectin. Liver biopsy showed intralobular inflammatory infiltrates, confluent necrosis and apoptosis, compatible with drug-induced liver disease. To our knowledge, this is the first case of ivermectin-induced severe liver disease published in the literature.

(c) 2006 Royal Society of Tropical Medicine and Hygiene. Published by Elsevier Ltd. All rights reserved.
\end{abstract}

\section{Case report}

In October 2000, a 20-year-old woman was referred to the Swiss Tropical Institute, Basle, Switzerland, for evaluation of a migrating worm in the sclera of her right eye (Figure 1). She reported general body itching over several years, headache and dizziness. She had lived in Cameroon until the age of 15; she had moved to Switzerland 5 years previously and had not visited Africa since then. She had had meningitis with subsequent persistent deafness and a history of hepatitis $A$ and B. Initial physical examination was inconspicuous except for moderate abdominal pain.

The worm that was removed from the patient's right eye was identified as an adult Loa loa, with a length of $2 \mathrm{~cm}$. Initial L. loa microfilaraemia was $820 / \mathrm{ml}$ of whole

\footnotetext{
* Corresponding author. Tel.: +41 76503 4259; fax: + 41612848183 .

E-mail address: oveit@yahoo.com (0. Veit).
}

blood. There was an eosinophilia of $18.5 \%$ (absolute count $350 / \mu \mathrm{l}$ ), and liver enzymes were normal. The patient was treated with albendazole $(600 \mathrm{mg} / \mathrm{d})$ for $21 \mathrm{~d}$. One month after the end of therapy, the microfilaraemia dropped to $250 / \mathrm{ml}$ and was still at this level 3 months thereafter (Table 1). Clinical signs and liver enzymes remained normal, and no abdominal pain was reported. A single dose of $15 \mathrm{mg}(300 \mu \mathrm{g} / \mathrm{kg})$ ivermectin, a dosage previously reported as having no major side effects (Kombila et al., 1998), was given to reduce the microfilaraemia further. At a routine follow-up 1 month after administration of ivermectin, the patient reported moderate new diffuse abdominal pain. Physical examination showed a new tenderness in the upper right quadrant; the liver was not enlarged. Laboratory investigation revealed elevated liver enzymes: ALAT $907 \mathrm{IU} / \mathrm{L}$ (normal range 7-42), ASAT $279 \mathrm{IU} / \mathrm{l}$ (normal range 5-39) and $\gamma \mathrm{GT} 66 \mathrm{IU} / \mathrm{l}$ (normal range 8-78); bilirubin, alkaline phosphatase, C-reactive protein, and red and white blood cell counts were in the normal range. Viral hepatitides were ruled out by means of serology (HAV, HBV, HCV, CMV, EBV). An HIV test was also negative. The patient had no his- 


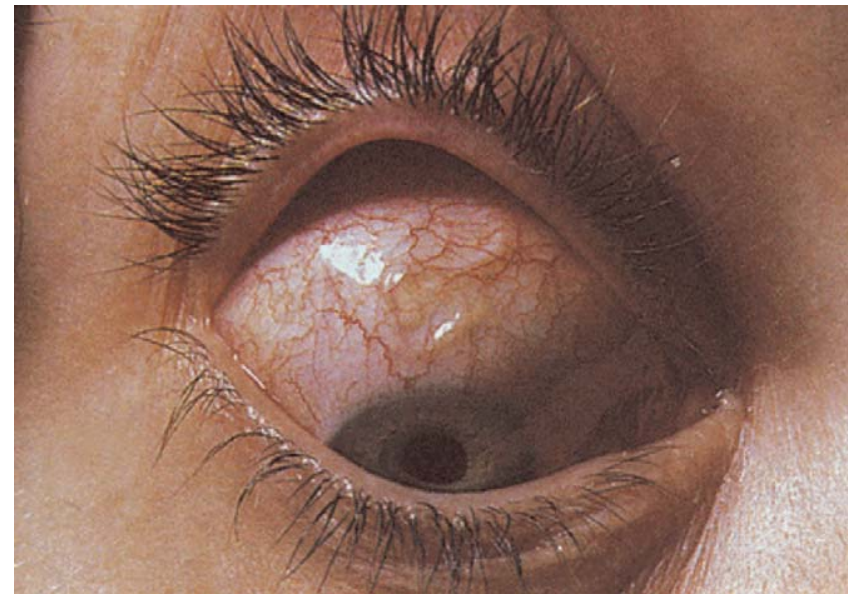

Figure 1 Transocular migration of the Loa loa macrofilariae $(2 \mathrm{~cm})$ in the patient.

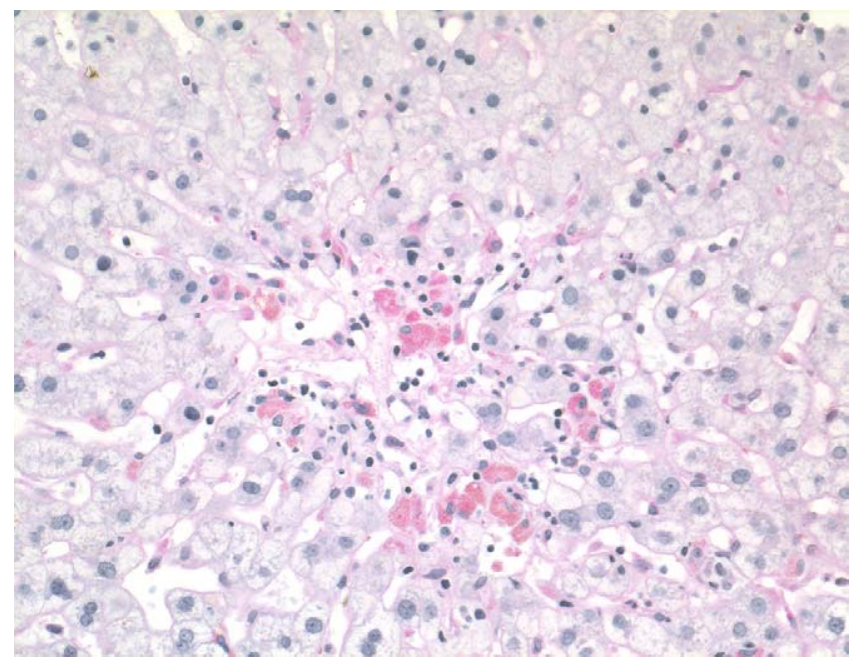

Figure 2 Liver biopsy with intralobular inflammatory infiltrates, focal ceroid loaded macrophages, perivenular confluent necrosis and intralobular apoptosis.

tory of alcohol or drug abuse. No other medications had been taken. A liver biopsy was performed, which showed predominantly perivenular intralobular inflammatory infiltrates, with conglomeration of ceroid loaded macrophages

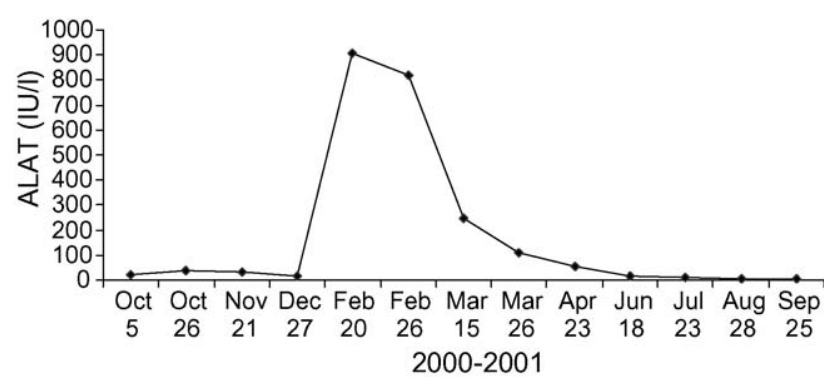

Figure 3 Follow-up of liver enzyme ALAT.

and confluent necrosis and apoptosis (Figure 2). The biopsy findings were consistent with resolving acute drug-induced hepatitis.

The patient became asymptomatic after a few days. Four months after the onset of hepatitis, all liver enzymes had returned to normal values (Table 1 and Figure 3). As microfilaraemia still persisted $(19 \mathrm{mf} / \mathrm{ml})$, diethylcarbamazine (DEC) was given for $29 \mathrm{~d}$ (total $7293.75 \mathrm{mg}$ ) and was well tolerated without any elevation of the liver enzymes. One week after initiating DEC treatment and in all subsequent examinations no microfilariae could be detected in the peripheral blood and no clinical sign of loiasis appeared.

\section{Discussion}

The filarial parasite $L$. loa is endemic in West and Central Africa, with an estimated 13 million people infected (Toure et al., 1998). Typical manifestations are transocular migration or subcutaneous swelling ('Calabar swelling'), caused by migrating adult nematodes (macrofilariae). Other common symptoms are generalized pruritus, fatigue and arthralgias. Hepatic dysfunction has not been reported. In exceptional cases, complications such as endomyocardial fibrosis and renal complications arise.

Diethylcarbamazine is the standard treatment of loiasis but is associated with an elevated risk of encephalitis in patients with high microfilaraemia (Carme et al., 1991). Ivermectin is used for treatment in many diseases, including loiasis, scabies, onchocerciasis and strongyloidiasis. In the treatment of onchocerciasis with ivermectin, where $L$. loa is endemic, encephalitis has been reported (Boussinesq et al., 1998; Ducorps et al., 1995; Gardon et al., 1997).

Table 1 Laboratory findings

\begin{tabular}{|c|c|c|c|c|c|c|c|}
\hline & \multicolumn{7}{|l|}{ Date } \\
\hline & $5 / 10 / 00$ & $27 / 12 / 00$ & $20 / 2 / 01$ & $26 / 03 / 01$ & $23 / 04 / 01$ & $13 / 7 / 01$ & $23 / 7 / 01$ \\
\hline Haemoglobin (g/dl) & 11.8 & 13.6 & 13.2 & 12.5 & & 12.4 & 12.1 \\
\hline Leucocytes $(10 \times 3 / \mu l)$ & 12.7 & 7.0 & 8.0 & 10.5 & & 8.7 & 9.5 \\
\hline Eosinophilia (\%) & 18.5 & 9.5 & 14.0 & 6.6 & & 4.5 & 6.5 \\
\hline ALAT [7-42 IU/l] & 21 & 35 & 907 & 111 & 54 & 23 & 13 \\
\hline ASAT [5-39 IU/l] & 23 & 23 & 279 & 47 & 27 & 20 & 5 \\
\hline$\gamma \mathrm{GT}[66-93 \mathrm{IU} / \mathrm{l}]$ & 22 & 42 & 66 & & & 27 & 27 \\
\hline Alkaline phosphatase [38-126 IU/l] & 58 & 40 & 61 & 57 & 43 & 46 & 38 \\
\hline Bilirubin $[2-24 \mu \mathrm{mol} / \mathrm{l}]$ & 11 & 8 & 22 & 16 & 20 & 21 & 13 \\
\hline Microfilaraemia (Loa loa) (/ml) & 820 & 220 & 9 & & & 19 & 0 \\
\hline
\end{tabular}


In our patient the results of the liver biopsy were compatible with drug-induced hepatotoxicity. At the time of the diagnosis of drug-induced liver disease, the patient had received two drugs in the previous 5 months: albendazole and ivermectin. Albendazole, which has good effect against L. loa microfilariae, was initially chosen over standard therapy with DEC because of the mentioned elevated risk of encephalitis in patients with high microfilaraemia. Albendazole can produce hepatotoxicity, but in most cases this is associated with the treatment of echinococcosis, in which elevations of enzymes occur as the cysts are destroyed (Horton, 1989). There are a few cases of drug-induced hepatitis in the literature (Morris and Smith, 1987). In our case, the interval of several months between treatment with albendazole and onset of symptoms, as well as the normal liver enzymes following this treatment, are reasons to think that albendazole was not the cause of this event.

The shorter interval between administration of ivermectin and the onset of symptoms, liver histology compatible with hepatocellular toxicity, and no history of other agents causing hepatitis all point to ivermectin as causative agent of the drug-induced liver disease in our patient. Idiosyncratic drug-induced liver disease occurs in 1-10 in 10000 patients taking a specific medicine. A review of published literature has not revealed any cases of severe ivermectin-induced liver disease, not even in escalating high doses of ivermectin (Guzzo et al., 2002). However, transient mild to moderate elevation of liver enzymes has been described (Biour et al., 2004; Zaha et al., 2002). Ivermectin is used for mass treatment against onchocerciasis, and also in L. loa endemic regions. However, a case like ours probably would not have been recognized in an area in Central Africa, where liver function tests are not routinely carried out, especially in the absence of jaundice. Furthermore, in a place where viral hepatitis is common, suspicion of druginduced hepatitis would be rather low. Therefore, in the absence of controlled large clinical trials there is the potential to miss such variants of hepatitis.

\section{Conclusion}

We consider ivermectin to be the cause of drug-induced hepatitis in our patient. To our knowledge, this is the first case of ivermectin-induced severe liver disease published in the literature. In patients suffering from abdominal pain after treatment with ivermectin, liver cell damage should be considered.

\section{Conflicts of interest statement}

The authors have no conflicts of interest concerning the work reported in this paper.

\section{Acknowledgement}

We wish to thank F. Vonmoos MD, Department of Ophthalmology, University Hospital Basle, for referring the patient to our department, and S. Krähenbühl MD, Department of Pharmacology, University Hospital Basle, for contributing pharmaceutical aspects.

\section{References}

Biour, M., Ben Salem, C., Chazouilleres, O., Grange, J.D., Serfaty, L., Poupon, R., 2004. Drug-induced liver injury; fourteenth updated edition of the bibliographic database of liver injuries and related drugs. Gastroenterol. Clin. Biol. 28, 720759.

Boussinesq, M., Gardon, J., Gardon-Wendel, N., Kamgno, J., Ngoumou, P., Chippaux, J.P., 1998. Three probable cases of Loa loa encephalopathy following ivermectin treatment for onchocerciasis. Am. J. Trop. Med. Hyg. 58, 461469.

Carme, B., Boulesteix, J., Boutes, H., Puruehnce, M.F., 1991. Five cases of encephalitis during treatment of loiasis with diethylcarbamazine. Am. J. Trop. Med. Hyg. 44, 684-690.

Ducorps, M., Gardon-Wendel, N., Ranque, S., Ndong, W., Boussinesq, M., Gardon, J., Schneider, D., Chippaux, J.P., 1995. Secondary effects of the treatment of hypermicrofilaremic loiasis using ivermectin. Bull. Soc. Pathol. Exot. 88, 105112.

Gardon, J., Gardon-Wendel, N., Demanga-Ngangue, Kamgno, J., Chippaux, J.P., Boussinesq, M., 1997. Serious reactions after mass treatment of onchocerciasis with ivermectin in an area endemic for Loa loa infection. Lancet 350, 18-22.

Guzzo, C.A., Furtek, C.I., Porras, A.G., Chen, C., Tipping, R., Clineschmidt, C.M., Sciberras, D.G., Hsieh, J.Y., Lasseter, K.C., 2002. Safety, tolerability and pharmacokinetics of escalating high doses of ivermectin in healthy adult subjects. J. Clin. Pharmacol. 42, 1122-1133.

Horton, R.J., 1989. Chemotherapy of Echinococcus infection in man with albendazole. Trans. R. Soc. Trop. Med. Hyg. 83, 97-102.

Kombila, M., Duong, T.H., Ferrer, A., Perret, J.L., Marion, M.C., Nguiri, C., Gaxotte, P., Manfoumbi, M., Richard-Lenoble, D., 1998. Short- and long-term action of multiple doses of ivermectin on loiasis microfilaremia. Am. J. Trop. Med. Hyg. 58, $458-460$.

Morris, D.L., Smith, P.G., 1987. Albendazole in hydatid disease-hepatocellular toxicity. Trans. R. Soc. Trop. Med. Hyg. 81, 343-344.

Toure, F.S., Mavoungou, E., Kassambara, L., Williams, T., Wahl, G., Millet, P., Egwang, T.G., 1998. Human occult loiasis: field evaluation of a nested polymerase chain reaction. Trop. Med. Int. Health 6, 505-511.

Zaha, O., Hirata, T., Kinjo, F., Saito, A., Fukuhara, H., 2002. Efficacy of ivermectin for chronic strongyloidiasis: two single doses given 2 weeks apart. J. Infect. Chemother. 8, 94-98. 